\title{
Synectic Multiliteration: Latest Findings in Poetry Writing Learning
}

\author{
Agung Nasulloh Saputro, Sahid Teguh Widodo ${ }^{2}$, Joko Nurkamto ${ }^{3}$, Kundharu Saddhono ${ }^{4}$ \\ \{goeng_15@yahoo.co.id ${ }^{1}$, sahidteguhwidodo@yahoo.com ${ }^{2}$, jokonurkamto@gmail.com ${ }^{3}$, \\ kundharu@uns.ac.id $\left.{ }^{4}\right\}$ \\ Doctoral Student of Sebelas Maret University, Surakarta, In don esia ${ }^{1}$, Facult y of T eacher \\ Train ing and Education Sebelas Maret Univ ersity, Surak arta, In do n esia ${ }^{2,3,4}$
}

\begin{abstract}
This article discusses the quality of direct learning models in learning to write poetry compared to multiliterated synectic learning models. This research uses a qualitative form with a descriptiveinterpretative approach. The results show: 1) the management of learning implementation used by lecturers meets quality requirements, seen from the completeness of the components of learning activities in the syllabus which consists of preliminary activities, implementation activities, and closing activities, 2) communicative processes can be concluded that the model learning used by lecturers, namely direct learning, demonstration learning, and problem solving learning models, 3) students' responses varies. The response of students in PGRI Madiun University, STKIP PGRI Ngawi, and ST KIP PGRI Ponorogo were very active and enthusiastic when attending lectures, on the contrary in ST KIP PGRI Pacitan and Catholic University Widya Mandala Madiun students were passive, 4) learning activities conducted by lecturers is monotonous and theoretical like in STKIP PGRI Pacitan and Widya Mandala Madiun Catholic University, conversely enjoyable learning activities and active students such as at PGRI Madiun University, ST KIP PGRI Ngawi, and ST KIP PGRI Pacitan, 5) Learning outcomes conducted by lecturers with written test and creation of works in the form of writing poetry.
\end{abstract}

Keywords: Poetry, Learning Model, Synectic and Multiliteration.

\section{Introduction}

Poetry introduces a formof literary work that uses semiotic symbols in an effort to convey a meaning of language desired by the author. Riffaterre (1978: 1) says that poetry is always changed by aesthetic concepts and tastes evolve according to the times. As a unique and variant literary work, poetry is formed from a variety of complex languages, it needs to be analyzed to understand it fully (Pradopo, 1990: 13). Thus, there needs to be a special form or standard in deepening the meaning of poetry. Some forms of analysis, such as: structural, semiotic, feminist, and psychology. The formof analys is chosen was adjusted to the focus of the study. One of them is the strata data analysis technique according to Roman Ingarden or often referred to as the phenomenological approach. The way this approach works starts from(1) the sound layer; (2) layers of meaning; (3) object layers; (4) layers of the world; and (5) layers of metaphosis (Pradopo, 1990: 15).

This makes it clear that in analyzing poetry not only requires a statement of the form and content of poetry, but also the need for deepening of meaning in conducting analysis. Apart from the meaning, the study of poetry in relation to learning, the analysis of poetry does not contain 
phases as well as in a learning model. For example, there are three phases in multiliteration studies, namely the preactivity phase, the activity phase, and the postactivity phase (Abidin, 2015: 105). Poetry analysis, if connected with various learning models, will certainly add to the creativity of poetry creation and produce a work that has special and unique values.

This implies that lecturers have a very central role in improving the quality of education. They have an important role not only in designing and implementing but also in assessing the learning process (Muhson, Lestari, Supriyanto, \& Baroroh, 2017: 199). The selection of an appropriate learning model is oriented towards teaching objectives, including the objectives of each material that will be discussed at each meeting given to students (Nadrah, Tolla, Ali, \& Muris, 2017: 123). The learning model is a conceptual framework that describes systematic procedures in organizing experiential learning to achieve specific learning goals, and serves as a guide for instructional designers and teachers in planning and implementing learning activities (Pitoyo, Waluyo, Kelvin, \& Andayani, 2014: 21). The steps in a learning model have their own peculiarities, including synectic learning models.

Synectic learning model is the stage of the learning model to describe various elements, using figures of s peech so as to obtain a new pers pective. The elements of the activity refer to the details or stages of the learning model activities so that the phases of the model activities are clearly identified. There are two elements of the synectic learning model, namely the learning model stage to create something new (creating something new) and the learning model stage to give preference to something unfamiliar (making the strange familiar) (Gordon \& Poze, 1980: 168). This is reinforced by the opinions of Tumangger and Ernidawati, (2012: 4) which states that synectics is a learning model for solving problems that can produce creative ideas and produce subjects freely. Therefore, the theory underlying the model is cognitive theory. Cognitive theory mostly focuses on the ability to think and solve problems creatively (Hosna, 2011: 4).

Mutmainah and Aquami(2016: 72) state about the streng ths of the synectic defense model. The advantages of this model, namely: 1) this model is usefulfor developing new understanding in students, about a problem, so that he is aware of how to behave in certain situations, 2) this model is usefulbecause it can develop clarity of understanding and internalization in students about the material new, 3) this model can develop creative thinking, both in students and teachers themselves, 4) this model is implemented in an atmosphere of intellectual freedom and equality between students, 5) This model helps students find new ways of thinking in solving a problem.

Weaknesses of synectic learning models, namely; 1) the synectic learning model is difficult for teachers and students to do, if they are accustomed to using old methods that emphasize the delivery of information;2) synectic learning model focuses on reflective and imaginative thinking in certain situations, then it is likely that students lack mastering the facts and procedures of implementation or skills (Huda, 2005: 89). In relation to the weaknesses of this model, it is necessary to have the latest learning activities because this synectic model only reaches producing learning outcomes. These activities such as; 1) test understanding, skills and knowledge;2) transferring knowledge and skills;3) presents work performance as a result of learning activities through social media. Additional learning activities are contained in multiliteration learning theory with the term postactivity.

Multiliteration is a new paradigmin learning literacy.Literacy itself has widened meaning 
it is not limited to reading and writing activities but is more complex to the practice of social and cultural accuracy that directs learners to recognize, understand, re-apply, and cultivate these socio-cultural values towards better. In fact, at present, literacy has led to dimensions as diverse as environmental literacy, literary literacy, media literacy, technological literacy, and even moral literacy. Literacy learning has implications for the emergence of the concept of multiliteration. Literacy according to Tomskin (in Resmini, 2008: 7) is the ability to use reading and writing in carrying out learning tasks both at school and outside of school.

The concept of multiliteration arises because humans not only read or write, but they read and write with certain genres that involve social, cultural, and political goals that are the demands of the globalization era, so this is the basis for the birth of multiliteration in the world of education. Multiliteration is a design that can be used to understand various types of texts and various forms of media produced fromvarious new technologies through pedagogical concepts that give teachers / lecturers the opportunity to present information to students using text and media forms (Abidin, 2015: 56).

The skills that must be mastered in order to create multiliteration learning are high comprehension reading skills, good writing skills, speaking skills, and skills in mastering various digital media (Morocco, 2008: 10). The four skills will not be separated from the mastery of literacy and the integration of language with other sciences to gain knowledge and be able to communicate that knowledge to others. With multiliteration learning, students can optimize their language skills so that critical thinking competence, conceptual, collaborative, and communicative competence arise and produce products in realizing the learning situation and be useful in creating conditions of inquiry-based learning and integrative thematic learning.

This study combines two learning models, namely the synectic learning model and the multiliteration learning model which is then referred to as the multiliterated synectic learning model. The advantages of this learning model, namely 1) this model has a detailed learning phase or stage, so that it can develop creative thinking, both in students and teachers themselves, 2) This model is useful because it can develop clearer understanding in students about new material, 3) this model is implemented in an atmosphere of intellectual freedomand dignity among students, 4) this model helps students find new ways of thinking in solving problems, 5) this learning model helps students to present their work as learning outcomes through social media.

\section{Literature Review}

This research is based on a constructivist paradigm that is useful to help students to internalize, reshape, or transform new information. Some key concepts used in this study, namely: the concept of poetry, the concept of learning models, synectic concepts, and the concept of multiliteration.

\section{Poetry}

Poetry is considered a valuable and authentic material for teaching language learners (Freyn, 2017). Poetry is ess entially a form of language pronunciation that takes into account aspects of the sounds in it that express the imainative, emotional, and intellectual experience of the poet 
drawn from an individual and social life, as outlined in a particular technique, so that the poemis able to evoke certain experiences in themselves readers or listeners (Sayuti, 2008: 3-4). Furthermore Bupu, Rukayah, \& Subiyanto (2018: 11) poetry is the oldest literary work that has the characteris tics of compacted language, meaningful language and elements of beauty (inner and physical).

\section{Learning Model}

Dilworth (1992: 74), states that models are abstract representations of some real world processes, systems, and subsystems. Models are used in all aspects of life. The model is useful in describing alternatives and in analyzing their performance. Dewey (in Joyce, Weil, \& Calhoun, 2000: 13) says that the es sence of the teaching process is the setting of environments in which students can interact and learn how to learn. Furthermore it is further explained that based on that, the teaching model is a description of the learning environment. The description has many uses, ranging from planning curricula, courses, units, and lessons to the design of teaching materials - books and workbooks, multi-media programs, and computer-assisted learning programs.

\section{Synetic}

Eristi \& Polat (2017: 72) states that synectics is a learning model that has an application structure or steps that can improve the quality of learning and make students more active in the learning process. Scheepers (2015: 73) also produced the same concept of synectics, namely synectics is a step to support creative behavior and stimulate creative thinking to produce new ideas. When learning, the creative problem solving process in the synectic learning model, feels difficult to do because it has become a habit of students to use conventional models. Therefore, synectics is designed to accommodate the stages of the learning model for developing creative skills.

\section{Multiliteration}

Multiliteration is the skill to use a variety of ways to express and understand ideas and information using conventional text forms as well as innovative texts, symbols and multimedia (Abidin, 2015: 3). Multiliteration practices conducted by Graham, Benson, and Fink (2010), are based on multimodal aspects of literacy which include linguistic competencies, visual competencies, audio competencies, gestural competencies, and spatial competencies where students are directed to utilize film media and performance programs in television as analytical material. Abidin (2015: 187) defines that "Learning the concept of multiliteration is an embodiment of the scientific learning process that optimizes literacy skills, namely literacy in reading, writing, speaking and mastery of information and communication media". 


\section{Method}

The research was conducted at the university of Madiun sekaresiden and carried out for three months namely from July 2019 to September 2019. The subjects in this study included lecturers of Indonesian language and literature education at PGRI Madiun University, STKIP PGRI Pacitan, STKIP PGRI Ponorogo, STKIP PGRI Ngawi, and University of Indonesian Literature Education Katolik Widya Mandala Madiun in semester 2 who took poetry appreciation courses, where from each course one lecturer and one representative clas s were chosen with \pm 20 students in each class.

This research is a qualitative study using an interpretive descriptive approach. The data in this study were collected through observations supplemented with observation guidelines, interviews based on interview guidelines and documents about the curriculum and its instruments (graduate competency standards, dis tribution and description of courses, syllabus, and learning implementation plans). Discussions and consultations with experts in the field of language education, language learning experts, and also literary experts conducted to obtain dataaccuracy.

\section{Research Result}

The quality of poetry writing learning is analyzed through effective learning theory according to Yusuf (2017: 16), namely a) the management of learning implementation, b) communicative process, c) students' responses, d) learning activities, and e) learning outcomes. Research findings can be described as follows.

\section{a) Management of Learning Implementation}

Management of learning implementation there are 3 main things that are in the syllabus, namely introduction, implementation, and closing (Yusuf, 2017: 1). The findings in the document analysis of the management of learning implementation can be described in the following table.

Table 1. Management of Learning Implementation that is Used by Lecturers

\begin{tabular}{|c|l|l|}
\hline No & \multicolumn{1}{|c|}{ Institution Name } & \multicolumn{1}{|c|}{ Management of Learning Implementation } \\
\hline 1 & Universitas PGRI Madiun & $\begin{array}{l}\text { In the syllabus there are learning activities which } \\
\text { include: preliminary activities, implementation } \\
\text { activities and closing activities. }\end{array}$ \\
\hline 2 & $\begin{array}{l}\text { Universitas Kat olik Widy a } \\
\text { Mandala Madiun }\end{array}$ & $\begin{array}{l}\text { In the syllabus there are learning activities which } \\
\text { include: preliminary activities, implementation } \\
\text { activities and closing activities. }\end{array}$ \\
\hline 3 & ST KIP PGRI Ponorogo & $\begin{array}{l}\text { In the syllabus there are learning activities which } \\
\text { include: preliminary activities, implementation } \\
\text { activities and closing activities. }\end{array}$ \\
\hline
\end{tabular}




\begin{tabular}{|c|l|l|}
\hline 4 & ST KIP PGRI Ngawi & $\begin{array}{l}\text { In the syllabus there are learning activities which } \\
\text { include: preliminary activities, implementation } \\
\text { activities and closing activities. }\end{array}$ \\
\hline 5 & ST KIP PGRI Pacitan & $\begin{array}{l}\text { In the syllabus there are learning activities which } \\
\text { include: preliminary activities, implementation } \\
\text { activities and closing activities. }\end{array}$ \\
\hline
\end{tabular}

From table 1., it can be concluded that the management of learning implementation used by lecturers of the Indonesian language and literature education study programat the Residency of Madiun has met the quality requirements, seen from the completeness of the components of learning activities in the syllabus which consists of preliminary activities, implementation activities, and activities cover.

\section{b) Communicative Process}

Communicative process is a learning system that emphasizes aspects of communication, interaction, and developing linguistic competence, and language skills as language learning goals and recognizes that there is a connection with communication activities in daily life (Yusuf, 2017: 18). The communicative process is seen from the process of delivering lecturer material through models, methods, and media. The findings in the syllabus document can be described in the following table 2 .

Table 2. Learning Models Used by Lecturers

\begin{tabular}{|c|l|l|}
\hline No & \multicolumn{1}{|c|}{ Institution Name } & \multicolumn{1}{|c|}{ Learning Model Used } \\
\hline 1 & Universitas PGRI Madiun & $\begin{array}{l}\text { Direct learning and demonstration } \\
\text { models. }\end{array}$ \\
\hline 2 & $\begin{array}{l}\text { Universita S Kat olik Widy a } \\
\text { Mandala Madiun }\end{array}$ & $\begin{array}{l}\text { Direct learning model using the lecture } \\
\text { method. }\end{array}$ \\
\hline 3 & ST KIP PGRI Ponorogo & Demonstration learning model \\
\hline 4 & ST KIP PGRI Ngawi & Problem solving learning model. \\
\hline 5 & ST KIP PGRI Pacitan & Direct learning model. \\
\hline
\end{tabular}

From the communicative process data based on syllabus documents, it can be concluded that the learning model used by lecturers of the Indonesian language and literature education study program in the residency of Madiun, namely the direct learning model, demonstration learning model, and problemsolving learning model. 


\section{c) Student Responses}

Student responses are the responses and reactions of students to the conditioning of learning conducted by the instructor, which includes aspects of the response and aspects of the reaction. The response aspect consists of enthusiasm, feeling, and attention, while the reaction aspect is satisfaction, curiosity, and pleasure (Yusuf, 2017: 19). From observations made by researchers obtained data that learning at the Widya Mandala Madiun Catholic University and STKIP PGRI Pacitan in the subject of poetry appreciation learning is monotonous, causing students to be passive. During the lecture, no students asked questions. Unlike STKIP PGRI Pacitan, in STKIP PGRI Ponorogo get data that students are very enthusiastic in attending lectures because the lecturer is able to present a real atmosphere in the classroom, through the illustrations made.

Observation of lectures at the University of PGRI Madiun and STKIP PGRI Ngawi produced datathat students are active in the clas sroom. During lectures students ask. The lecturer has competence in managing the class because the learning is interesting and not monotonous. From these observational data it can be concluded that the response of students varies. Three universities, namely PGRI Madiun University, STKIP PGRI Ngawi, and STKIP PGRI Ponorogo describe the response of students to be very active and enthusiastic when attending lectures, while in STKIP PGRI Pacitan and Catholic University Widya Mandala Madiun students are passive. During lectures and no students asked questions.

\section{d) Learning Activities}

Learning activities are the activities of teachers and students in class, which includes mentalactivities, listening activities, visual activities, writing activities, oral activities, drawing activities, motor activities, and emotional activities (Yusuf, 2017: 19). Learning activity data is taken from observations made by researchers in the learning process. The results of learning activities can be described in table 3 below.

Table 3. Learning Activities Conducted by Lecturers and Students

\begin{tabular}{|c|l|l|}
\hline No & \multicolumn{1}{|c|}{ Nama Institusi } & \multicolumn{1}{c|}{ Aktivitas Belajar } \\
\hline 1 & Universitas PGRI Madiun & $\begin{array}{l}\text { Within } 2 \times 50 \text { minutes, the lecturer only } \\
\text { used the lecture method to deliver the material, } \\
\text { interspersed with poetry readings and with several } \\
\text { questions and answers. }\end{array}$ \\
\hline 2 & $\begin{array}{l}\text { Universitas Kat olik Widya } \\
\text { Mandala Madiun }\end{array}$ & $\begin{array}{l}\text { Within } 2 \times 50 \text { minutes, the lecturer only } \\
\text { uses the lecture method to deliver the material. At } \\
\text { the end of the lesson, the lecturer gives the task of } \\
\text { writing poetry. }\end{array}$ \\
\hline
\end{tabular}




\begin{tabular}{|c|l|l|}
\hline 3 & ST KIP PGRI Ponorogo & $\begin{array}{l}\text { The lecturer gave a demonstration to the } \\
\text { students about reading poetry with full appreciation. } \\
\text { Lecturers are able to attract students' attention to the } \\
\text { material being taught. The lecturer is not trapped in } \\
\text { teaching about theories, but directly discusses } \\
\text { poetry directly. }\end{array}$ \\
\hline 4 & ST KIP PGRI Ngawi & $\begin{array}{l}\text { Within } 2 \times 50 \text { minutes, the lecturer gave his } \\
\text { innovation by making creative students in the } \\
\text { classroom. The lecturer gives a word to be continued } \\
\text { into a poem }\end{array}$ \\
\hline 5 & ST KIP PGRI Pacitan & $\begin{array}{l}\text { Learning only applies in one direction, } \\
\text { monotonous, and theoretical. There is no standard } \\
\text { learning model for developing student innovation. }\end{array}$ \\
\hline
\end{tabular}

From table 3. it can be concluded that the learning activities carried out by lecturers and students are very diverse. The findings of learning activities state that learning is monotonous, one-way, and theoretical as in STKIP PGRI Pacitan and Widya Mandala Madiun Catholic University, conversely enjoyable learning activities and active students such as at PGRI Madiun University, STKIP PGRI Ngawi, and STKIP PGRI Pacitan.

\section{e) Learning Outcomes}

Learning outcomes are abilities (cognitive, affective, and psychomotor) possessed by students after experiencing the learning process of the instructor (Joseph, 2017: 19). Analys is of the document on the syllabus conducted by researchers produced data, namely 1) Ardi Wina Saputra used posttest, there was no task of creating poetry, 2) Sutejo used tests and non-tests, tests in the form of posttest and non-test in the form of creating poetry. 3) Panji Kuncoro must use the task of writing poetry. 4) Tjahono Widijanto used a written test, and 5) Arif Mus tofa used the task of writing poetry. Based on the analysis of the document, the learning outcomes conducted by the lecturer with written tests and the creation of works in the form of writing poetry. The evaluation format in the syllabus is not specified in detail. From the findings of researchers on the quality of learning to write poetry conducted by lecturers of Indonesian language and literature education at the Residency of Madiun, it can be concluded that the quality of learning conducted by lecturers is still of poor quality because it is found that some lecturers in teaching are still theoretical and monotonous, students are very passive, and not there is an as ses sment format in learning to write poetry.

\section{Discussion}

\section{Synectic Multiliteration as a Millennial Era Learning Model}

Synectic is a learning model that has an applicative structure or steps that can improve the quality of learning and make students more active in the learning process of Eristi \& Polat (2017: 72). Scheepers (2015:73) also produced the same concept of synectics, namely synectics is a step 
to support creative behavior and stimulate creative thinking to produce new ideas. When learning, the creative problem solving process in the synectic learning model, feels difficult to do because it has become a habit of students to use conventional models.

Synectic learning model is a learning model that is designed to enhance thecreativity of both individuals and groups (Joyce, Weil, and Calhoun, 2009: 272). Creative concepts in synectic learning models are also produced in articles made by Tumangger and Ernidawati, (2012:4), namely synectic learning models are learning models for solving problems that can produce creative ideas and produce subjects freely. Sutikno states that synectics is a learning model that is oriented to problem solving, creative, social experiences of students (2016: 223).

Opinion that becomes a differentiator related to the understanding of synectic learning models, namely the opinion of Aziz, (2009: 131) states that the synectic learning model is an activity in the form of a creative problem solving processby using analogies. Karwati stated that the synectic learning model is a learning model that emphasizes meaningful ideas to enhance creative activities through the help of richer minds (2012: 150).

Mutmainah and Aquami (2016: 72) state about the strengths and weaknesses of the synectic defense model. The advantages of this model, namely: 1) this model is useful for developing new understanding in students, about a problem, so that he is aware of how to behave in certain situations, 2) this model is useful because it can develop clarity of understanding and internalization in students about the material new, 3) this model can develop creative thinking, both in students and teachers themselves, 4) this model is implemented in an atmosphere of intellectualfreedomand equality between students, 5) This model helps students find new ways of thinking in solving a problem.

Weaknesses of this learning model, namely: 1 ) it is difficult to do by teachers and students who are accustomed to using the old way that emphasizes the delivery of information, 2) this model focuses on reflective and imaginative thinking in certain situations, then it is likely that students lack mastering facts and implementation procedures or skills, and 3) inadequate education facilities and infrastructure in schools.

In the era of digital information technology, a writer and poet must be able to adjust the conditions of the digital age. The emergence of new technologies for students around the world will add to the learning experience automatically. As educators, a new methodology must be adopted to deal with students from various backgrounds (Rajendra, 2015: 11). One of the main aspects in this context is the changing nature of the text that has been developed fromadvances in technology (Elsner, 2011:29). With such conditions, learning to write poetry that is made and read cannot be separated frommultimodality. Baldry \& Thibault (2006) describe multimodality as a variety of ways in which various semiotic sources interact and interpret meaning.

In relation to the weaknesses of this model, it is necessary to have the latest learning activities because this synectic model only reaches producing learning outcomes. These activities such as; 1) test understanding, skills and knowledge; 2) transferring knowledge and skills; 3) presents work performance as a result of learning activities through social media. Additional learning activities are contained in multiliteration learning theory with the term postactivity.

Multiliteration is a new paradigmin learning literacy. Literacy itself has widened meaning it is not limited to reading and writing activities but is more complex to the practice of social and cultural accuracy that directs learners to recognize, understand, re-apply, and cultiv ate these sociocultural values towards better. In fact, at present, literacy has led to dimensions as diverse as 
environmental literacy, literary literacy, media literacy, technological literacy, and even moral literacy. Literacy learning has implications for the emergence of the concept of multiliteration. Literacy according to Tomskin (in Resmini, 2008: 7) is the ability to use reading and writing in carrying out learning tasks both at school and outside of school.

The concept of multiliteration arises because humans not only read or write, but they read and write with certain genres that involve social, cultural, and political goals that are the demands of the globalization era, so this is the basis for the birth of multiliteration in the world of education. Multiliteration is a design that can be used to unders tand various types of texts and various forms of media produced from various new technologies through pedagogical concepts that give teachers / lecturers the opportunity to present information to students using text and media forms (Abidin, 2015: 56). The skills that must be mastered in order to create multiliteration learning are high comprehension reading skills, good writing skills, s peaking skills, and skills in mastering various digital media (Morocco, 2008: 10).

Multiliteration is a theoretical innovation in res ponding to rapid changes in economic, social, and cultural life (Sang, 2017: 19). Abidin (2015: 105) states that multiliteration related to learning has three phases, namely the preactivity phase, the activity phase, and the postactivity phase. The preactivity phase is the preparation phase of learning undertaken by students, including: a) setting the theme, b) creating a framework, c) understanding the framework of thought, ideas, and concepts, d) understanding the learning objectives, and e) linking the context to be learned with himself, his life, and other contexts that have been studied. The activity phase is the phase by students to follow the process or learning activities, including: a) reading texts, b) writing drafts, c) conveying ideas and ideas through oral and written, d) summarizing information, and e) testing, criticizing, and analyze social phenomena. Postactivity phase is a phase that reflects the success of students in participating in learning, including: a) testing understanding, skills, and knowledge, b) presenting student work as a result of learning, c) transferring knowledge and skills, and d) organizing an exhibition of work results from learning activities (Abidin, 2015: 105-106).

With these two learning models, In the era of digital information technology, a writer and poet reader must be able to adjust the conditions of the digital era. The emergence of new technologies for students around the world will add to the learning experience automatically. As educators, a new methodology mustbe adopted to deal with students from various backgrounds (Rajendra, 2015: 11). One of the main as pects in this context is the changing nature of the text that has been developed fromadvances in technology (Elsner, 2011:29). Given these conditions, it is neces sary to develop innovative models, one of which is multiliterated synectic learning models . The multiliteration synectic learning model is a learning model that is sourced from cognitive theory which has systematic steps in the form of a preactivity phase, an activity phase, work based on social experiences.

The stages of the multiliteration synectic model, namely: 1) the preactivity phase, namely substantive input; lecturers provide information on new topics, 2) Activity phase, consisting of: a) a direct analogy namely; lecturers submit a direct analogy and ask students to describe the analogy, b) personal analogy, namely; The lecturer asks students to make a pers onal analogy, c) to compare analogies namely; Students identify and explain the same points between the material being discussed in a direct analogy, d) explain the differences. students explain wrong or different analogies, e) student exploration namely; reexplain the original topic according to the 
language itself, f) bring up a new analogy namely; students make work, 3) Postactivity phase, consisting of students demonstrating a new analogy in the formof poetry in front of the audience and uploaded on social media.

\section{Conclusions}

From the results of this study, it can be concluded that the quality of poetry writing learning conducted by Indonesian language and literature education lecturers in the Residency of Madiun can be concluded that the quality of learning conducted by lecturers is still of poor quality because it is found that severallecturers in teaching are still theoretical and monotonous, students are very passive, and there is no evaluation format in learning to write poetry.

With these qualities, it is necessary to develop multiliterated synectic learning models. The multiliteration synectic learning model is a learning model that is sourced from cognitive theory which has systematic steps in the form of a preactivity phase, an activity phase, and a postactivity phase to improve literacy and creative thinking abilities in the creation of a work based on social experiences.

\section{References}

[1] Riffaterre, M. (1978). Semiotics of Poetry. London: Indiana of University Press.

[2] Pradopo, R. D. (1990). Pengkajian Puisi. Yogyakarta: Gadjah Mada University Press.

[3] Abidin, Y. (2015). Pembelajaran Multiliterasi. Bandung: PT Refika Aditama.

[4] Muhson, B. L., Supriyanto., \& Baroroh, K. (2017). The Development of Practical Item AnalysisProgram for Indonesian Teachers. International Journal of Instruction, 10 (2), 199-210.

[5] Nadrah., Tolla, I., Ali, M.S., \& Muris. (2017). The Effect of Cooperative Learning Model of Teams Games Tournament (TGT) and Students' Motivation toward Physics Learning Outcome. International Education Studies, 10 (2), 123-130.

[6] Pitoyo, A., Waluyo, H. J., Suwandi, S., \& Andayani. (2014). The Effect of Group In vestigation Learning Model, Accelerated Learning T eam and Role Playing on Elementary School Students' Writing Skills Viewed from Cognitive Style. Journal of Education and Practice, 5 (1), 21-29.

[7] Gordon, W.J.J., \& Poze, T. (1980). SES Synectics and Gifted Education Today. Sage Publication. Graham, Meadow Sherril, Sheila Benson, \& Lisa Storm Fink. 2010. A Springboard Rather Than a Bridge: Diving into Multimodal Literacy. English Journal (High School Edition). 200(1),140-153.

[8] Tumanger, M., \& Ernidawati, T. (2012). The application of synectics model to improve students' speaking ability in senior high school. TRANSFORM Journal of English Language Teaching and Learning of FBS UNIMED, 1 (2), 1-8.

[9] Hosna, R. (2013). Pengembangan Model Pembelajaran Sinektik di Mad"asah I'tidaiyah. Jurnal UIN Sunan Gunung Djati Bandung, 28 (2), 237-252.

[10] Mutmainah, Ummi dan Aquami. (2016). Penerapan Model Pembelajaran Sinektik Terhadap Kreativitas Belajar Siswa pada Mata Pelajaran Ilmu Pengetahuan Alam Kelas V Madrasah Ibtidaiyah Hijriah 2 Palembang. Jurnal Ilmiah PGMI, 2 (1), 69-82.

[11] Huda, Miftahul. (2005). Model-Model Pengajaran dan Pembelajaran. Yogyakarta: Pustaka Pelajar. [12] Resmini, N. (2008). Membaca dan Menulis di Sekolah Dasar. Bandung: UPI Press.

[13] Morocco, C.C. (2008). Supported Literacy for Adolescents: Transforming Teaching and Content Learning for The Twenty-First Century. San Fransisco: Jossey-Bass Wiley Inprint.

[14] Freyn, Amy. L. (2017). Effects of a Multimo dal Approach on ESL/EFL University Students' Attitudes towards Poetry. Journal of Education and Practice. 8(8), 9-20. 
[15] Sayuti, S. A. (2008). Berkenalan Dengan Puisi. Yogyakarta: Gama Media.

[16] Bupu, Servasius, Rukayah, \& Slamet Subiyantoro. (2018). Influence of Writing Poetry Module Using in Contextual Learning to Writing Poetry Learning Result of Elementary Student. International Journal of Multicultural and Multireligious Underst anding (IJMMU), 5(2), 9-18.

[17] Dilworth, J.B. 1992. Operations Management: Design, Planing and Control for Manufacturing. New York: Longman.

[18] Joyce, Bruce, Weil, Marsha, dan Calhoun, Emily. 2000. Models of Teaching. Boston: Library of Congress Cataloging-in-Publication Data.

[19] Eristi, B., \& Polat, M. (2017). The Effectiveness Of Synectics Instructional Model On Foreign Language Vocabulary T eaching. International Journal of Languages' Education and Teaching, 5 (2), 59-76.

[20] Scheepers., J de Villiers, M., \& Maree, L. (2015). Fostering Team Creativity in Higher Education Settings. e-Journal of Business Education \& Scholarship of Teaching, 9 (1), 70-86.

[21] Yusuf, Bistari Basuni (2017). Konsep dan Indikator Pembelajaran Efektif. Jurnal Kajian

[22] Aziz, R. (2009). Pengembangan Kreativitas Melalui Kegiatan Sinektik. Jurnal Intervensi Psikologi, 1 (2). 129-142.

[23] Karwati, U. (2012). Aplikasi model pembelajaran sinektik (Synectic model). Jurnal Seni dan Budaya Panggung, 22 (2), 147-159.

[24] Rajendra, Thusha Rani. (2015). Multimodality in Malaysian Schools: The Case for the Graphic Novel. The Malaysian Online Journal of Educational Science, 3(2),11-20.

[25] Elsner, Daniela. (2011). Developing multiliteracies, plurilingual awareness \& critical thinkingvin the primary language classroom with multilingual virtual talkingbooks. Encuentro 20, 27-38.

[26] Baldry, A., \& Thibault, P. (2006). Multimodal transcription and text analysis: A multimodal toolkit and coursebook. London, UK: Equinox.

[27] Sang, Yuan. (2017). Expanded Territories of "Literacy”: New Lit eracies and Multiliteracies. Journal of Education and Practice, 8(8), 16-19. 
